\title{
Determinants of Corporate Social Responsibility Disclosure Ratings by Spanish Listed Firms
}

\section{Carmelo Reverte}

Departamento de Economía, Contabilidad y Finanzas

Universidad Politécnica de Cartagena

Corresponding author: C. Reverte Maya

Tel: +34.968 .32 .59 .25$

E-mail: carmelo.reverte@upct.es
ABSTRACT. The aim of this paper is to analyze whether a number of firm and industry characteristics, as well as media exposure, are potential determinants of corporate social responsibility (CSR) disclosure practices by Spanish listed firms. Empirical studies have shown that CSR disclosure activism varies across companies, industries, and time (Gray et al., Accounting, Auditing \& Accountability Journal 8(2), 47-77, 1995; Journal of Business Finance E Accounting 28(3/4), 327-356, 2001; Hackston and Milne, Accounting, Auditing \& Accountability Journal 9(1), 77-108, 1996; Cormier and Magnan, Journal of International Financial Management and Accounting 1(2), 171-195, 2003; Cormier et al., European Accounting Review 14(1), 3-39, 2005), which is usually justified by reference to several theoretical constructs, such as the legitimacy, stakeholder, and agency theories. Our findings evidence that firms with higher CSR ratings present a statistically significant larger size and a higher media exposure, and belong to more environmentally sensitive industries, as compared to firms with lower CSR ratings. However, neither profitability nor leverage seem to explain differences in CSR disclosure practices between Spanish listed firms. The most influential variable for explaining firms' variation in CSR ratings is media exposure, followed by size and industry. Therefore, it seems that the legitimacy theory, as captured by those variables related to public or social visibility, is the most relevant theory for explaining CSR disclosure practices of Spanish listed firms.

KEY WORDS: corporate social responsibility disclosure, Spain

\section{Introduction}

Over the last few decades there has been a growing public awareness of the role of corporations in society. Many of the firms which have been credited with contributing to economic and technological progress have been criticized for creating social problems. Issues such as pollution, waste, resource depletion, product quality and safety, the rights and status of workers, and the power of large corporations have become the focus of increasing attention and concern. In this context, companies have been increasingly urged to become accountable to a wider audience than shareholder and creditor groups. As a matter of fact, public awareness and interest in environmental and social issues and increased attention in mass media have resulted in more social disclosures from corporations in the last two decades (Deegan and Gordon, 1996; Gray et al., 1995; Hooghiemstra, 2000; Kolk, 2003). In the European Union context, the publication of the Green Paper (2001) by the European Commission launched a wide debate on how the EU could promote corporate social responsibility (CSR). Although there is still no universal definition of CSR (Godfrey and Hatch, 2007), most definitions describe it as a concept whereby companies integrate social and environmental concerns in their business operations and in their interaction with their stakeholders on a voluntary basis. By acting in a responsible way to the variety of social, environmental, and economic pressures, companies respond to the expectations of the various stakeholders with whom they interact, such as employees, shareholders, investors, consumers, public authorities, and non-governmental organizations (NGOs).

Companies usually inform of their CSR activities in the annual report or in separate social reports (CSR Report or Sustainability Report). However, there is no standardization or uniformity in terms of the items reported, or the way of reporting. 
Consequently, various NGOs have started developing models or frameworks for reporting on CSR, such as the ISO 14001 (Internationally Standards Organization), World Resources Institute (WRI) and the Global Reporting Initiative (GRI).

With regard to the empirical research on CSR, three types of empirical studies characterize the research in this field. The first one relates to 'descriptive studies,' which report on the nature and extent of CSR with some comparisons on countries and periods. The second one is related to 'explicative studies,' which focus on the potential determinants of social and environmental reporting. The third one is interested in the 'impact of social and environmental information' on various users, mainly on market reaction. Our study adopts the second orientation, as it is focused on analyzing whether a number of firm and industry characteristics, as well as media exposure, are potential determinants of CSR disclosure practices by Spanish listed firms. Empirical studies have shown that CSR disclosure activism varies across companies, industries, and time (Gray et al., 1995, 2001; Hackston and Milne, 1996). They have also shown this behavior to be importantly and systematically determined by a variety of firm and industry characteristics that influence the relative costs and benefits of disclosing such information (Belkaoui and Karpik, 1989; Cormier and Magnan, 2003; Cormier et al., 2005; Hackston and Milne, 1996; Patten, 2002a, b).

This paper is focused on the Spanish setting for three reasons. First, most of the present literature is based on Anglo-American countries (US and UK) and evidence should be added about other institutional contexts. Second, there is scarce empirical research on CSR determinants by Spanish companies. Previous studies (Archel, 2003; Archel and Lizarraga, 2001; Carmona and Carrasco, 1988; Garc1 'a-Ayuso and Larrinaga, 2003; Moneva and Llena, 1996, 2000) have mainly focused on one dimension of CSR such as environmental disclosure, and the sample periods analyzed in these papers were previous to the first compulsory regulations in Spain in the area of environmental disclosure (i.e., the Royal Decree 437/1998 and the Resolution enacted on March 25, 2002 by the Institute of Accounting and Auditing - ICAC-). Our sample period follows the previous mandatory regulations and also the GRI Sustainability Reporting Guidelines, which have been generally adopted by Spanish listed firms in the last years as the benchmark for CSR reporting. As a result, CSR disclosures by Spanish firms in our sample period are much more richer and extensive as compared to previous studies in the Spanish context in which that information was very scarce and anecdotical. Moreover, our measure of CSR not only captures environmental issues but also a number of social aspects included in the latest developments in CSR worldwide, specially those stemming from the GRI Sustainability Reporting Guidelines and the United Nations Norms on the Responsibilities of Transnational Corporations and Other Business Enterprises with regard to Human Rights. Third, in contrast to the understanding of CSR from common law English-speaking countries (Australia, Canada, UK, US), the determinants of CSR in Continental Europe are still relatively unknown. Therefore, our main goal is to analyze whether the specific features of Spain regarding its capital market and companies' financing structure result in a significant difference between the factors influencing CSR disclosure practices of Spanish listed firms when compared to firms from other different institutional contexts. In particular, Spain is less capital market oriented than other EU countries and financing policies are bank oriented.

The remainder of the paper is organized as follows. In the following section, the theoretical framework used is presented. Section "Determinants of CSR disclosure: development of hypotheses" discusses the determinants of CSR disclosure practices. Section "Data and method of estimation" focuses on the methodology and data. Section "Results" presents the main results of our empirical analysis. Finally, some conclusions are drawn.

\section{A multi-theoretical framework for CSR disclosure}

Despite widespread academic and business interest in the issue, a comprehensive theoretical framework of the underlying determinants of corporate social and environmental reporting is still elusive. The empirical investigations of CSR practices have produced a very diverse body of academic literature which engages different theoretical perspectives in support of corporate social reporting, such as the agency 
theory, the legitimacy theory, and the stakeholder theory, among others.

For instance, there is extensive evidence that social and environmental information is useful for decision-making by financial stakeholders (Blacconiere and Northcut, 1997; Blacconiere and Patten, 1994; Graham et al., 2000; Richardson and Welker, 2001). However, with its financial stakeholders' focus, it fails to provide a comprehensive theoretical foundation to explain CSR disclosure, especially since most of that disclosure is nonfinancial. In response to this conceptual gap, other alternative explanations for CSR disclosure have also been offered in the literature. Following its emergence as an explanatory model for corporate financial reporting (Watts and Zimmerman, 1986), economic agency theory (or positive accounting theory) became an appealing proposition as a rationale for CSR disclosure (Belkaoui and Karpik, 1989). Agency theory views the firm as a nexus of contracts between various economic agents who act opportunistically within efficient markets. In this context, social and environmental disclosure may prove useful in determining debt contractual obligations, managerial compensation contracts, or implicit political costs. However, as indicated by Cormier et al. (2005), agency theory's focus on monetary or wealth considerations among agents who trade in informationally efficient markets does limit the scope of relevant social and environmental disclosure as well as its intended purpose, insofar as many potential users of this kind of information may not act in these markets at all (e.g., pressure groups such as Greenpeace).

In contrast to agency theory, the legitimacy theory provides a more comprehensive perspective on CSR disclosure as it explicitly recognizes that businesses are bound by the social contract in which the firms agree to perform various socially desired actions in return for approval of their objectives and other rewards, and this ultimately guarantees their continued existence (Brown and Deegan, 1998; Deegan, 2002; Guthrie and Parker, 1989). Gray et al. (1995) a n d H o o g h i e m s t r a ( 2000), among others, argue that most insights into CSR disclosure ema-nate from the use of this theoretical framework which posits that social and environmental disclosure is a way to legitimize a firm's continued existence or operations to the society. Perrow (1970) defines legitimacy as a generalized perception or assumption that the actions of an entity are desirable, proper, or appropriate within some socially constructed system of norms, value, beliefs, and definitions. Although firms have discretion to operate within institutional constraints, failure to conform to critical, institutionalized norms of acceptability can threaten the firm's legitimacy, resources, and, ultimately, its survival (DiMaggio and Powell, 1983; Oliver, 1991; Scott, 1987). Meyer and Rowan (1977) assert that: 'as the issues of safety and environmental pollution arise, and as relevant professions and programs become institutionalized in laws, union ideologies and public opinion, organizations incorporate these programs and professions' (Meyer and Rowan, 1977, p. 345). Jennings and Zandbergen (1995) argue that the type of institutional pressure, be it coercive, mimetic, or normative, influences the rate at which sustainable development practices diffuse among firms. Reinforcing the previous arguments, many prior studies on corporate disclosures have provided evidence that firms do voluntarily disclose information in their annual reports as a strategy to manage their legitimacy (Campbell, 2000; Deegan and Rankin, 1996; Hutchings and Taylor, 2000; Nasi et al., 1997; Patten, 1991; Woodward et al., 2001). Thus, CSR disclosure can be viewed as a constructed image or symbolic impression of itself that a firm is conveying to the outside world to control its political or economic position (Neu et al., 1998).

Finally, the stakeholder theory explicitly considers the expectations impact of the different stakeholder groups within society upon corporate disclosure policies. Under the managerial branch of stakeholder theory, the central thesis that emerges is that corporate disclosure is a management tool for managing the informational needs of the various powerful stakeholder groups (employees, shareholders, investors, consumers, public authorities and NGOs, ...). Managers use information to manage or manipulate the most powerful stakeholders in order to gain their support which is required for survival (Gray et al., 1996). In relation to the overlap between legitimacy theory and stakeholder theory, Deegan (2002, p. 295) state that "both theories conceptualise the organisation as part of a broader social system wherein the organisation impacts, and is impacted by, other groups within society. Whilst legitimacy 
theory discusses the expectations of society in general (as encapsulated within the 'social contract'), stakeholder theory provides a more refined resolution by referring to particular groups within society (stakeholder groups). Essentially, stakeholder theory accepts that because different stakeholder groups will have different views about how an organisation should conduct its operations, there will be various social contracts 'negotiated' with different stakeholder groups, rather than one contract with society in general. Whilst implied within legitimacy theory, stakeholder theory explicitly refers to issues of stakeholder power, and how a stakeholder's relative power impacts their ability to 'coerce' the organisation into complying with the stakeholder's expectations."

While there are some similarities, the previous three alternative theories essentially differ on the basis of fundamental assumptions. Unlike the agency or positive accounting theory, legitimacy theory and stakeholder theory make no assumption of rational, wealth-maximizing individuals operating within the environment of efficient capital markets. On the other hand, while Woodward et al. (1996) have shown that both legitimacy theory and stakeholder theory consider an organization to be part of the wider social system, legitimacy theory looks at society as a whole, whereas stakeholder theory recognizes that some groups within the society are more powerful than others. We posit that the alternative theories which are of value in studies of CSR disclosure policies focus upon distinct perspectives of the same issue. Hence, the different theories outlined should not be seen as competing perspectives, but rather as alternative ways of comprehending and studying organizational decisions to disclose different kinds of information to the public.

\section{Determinants of CSR disclosure: development of hypotheses}

Empirical studies have shown that CSR disclosure activism varies across companies, industries, and time (Gray et al., 1995, 2001; Hackston and Milne, 1996). They have also shown this behavior to be importantly and systematically determined by a variety of firm and industry characteristics that influence the relative costs and benefits of disclosing such information (Belkaoui and Karpik, 1989; Cormier and Magnan, 2003; Cormier et al., 2005; Hackston and Milne, 1996; Patten, 2002a, b). The theories that seem to have been most successful in explaining the content and extent of social and environmental reporting are system-oriented theories, above all legitimacy and stakeholder theories (Gray et al., 1995; Milne, 2002). According to these theories, social disclosure is in first hand used in order to guard corporations' reputation and identity (Hooghiemstra, 2000). Both Adrem (1999) and Cormier et al. (2005) argue, however, that disclo-sures are a complex phenomenon that cannot be explained by one single theory. As pointed out by Gray et al. (1995), if the aim of the study is to ex-plain an empirical phenomenon, it could be a problem when theories are looked upon as com-petitive instead of complementary. Hence, in this study we have an eclectic approach and use a multi-theoretical framework in order to explain the dif-ferences in CSR disclosure practices between Spanish listed firms. Next, we discuss each of the explanatory factors analyzed.

Size

The public pressure perspective of legitimacy theory is concerned with public and, consequently, government intrusions into the activities of organizations that are deemed to violate their social contract. This perspective parallels Watts and Zimmerman's (1986) political cost hypothesis in that larger companies are deemed to be more highly exposed to public scrutiny. Watts and Zimmerman (1986) argue that large companies are more visible to the public, have more market power, and are more newsworthy. Hence, they are more likely to be subject to public resentment, consumer hostility, militant employees, and the attention of government regulatory bodies. Large corporations do have a bigger effect on the community, and therefore normally have a bigger group of stakeholders that influence the corporation (Hackston and Milne, 1996; Knox et al., 2006). Hence, voluntary disclosures can be explained as an effort to avoid regulations and reduce political costs (Adams et al., 1998; Clarke and Gibson-Sweet, 1999; Gray et al., 1995; Ness and Mirza, 1991). Dowling and Pfeffer (1975) argue that 
larger firms are more politically visible, thus they are expected to engage more heavily in legitimating behavior. From an empirical perspective, various studies have found that there is a positive relationship between CSR disclosure and firm size or political visibility (Adams et al., 1998; Cullen and Christopher, 2002; Hamid, 2004; Haniffa and Cooke, 2005; Hossain et al., 1995; Neu et al., 1998; Patten, 1991). Hence, the discussion above leads us to the hypothesis that:

H1: There is a positive significant relationship between firm size and CSR disclosure.

\section{Industry sensitivity}

In previous research, industry, together with size, is the most common variable in order to explain the content and extent of social and environmental disclosures (Adams et al., 1998; Cowen et al., 1987; Gray et al., 1995). The results from these studies show that corporations from industries whose manufac-turing process has a negative influence on the environment disclose and report considerably more information than corporations from other industries. In general, corporations from the mining, oil, and chemical industries emphasize information regarding environmental, health, and safety issues (Clarke and Gibson-Sweet, 1999; Jenkins and Yakovleva, 2006; Line et al., 2002; Ness and Mirza, 1991), while the finance and service industries in general seem to report more regarding social issues and philanthrop-ical deeds (Clarke and GibsonSweet, 1999; Line et al., 2002). A body of empirical literature associates the metals, resources, paper and pulp, power gener-ation, water, and chemicals sectors with high envi-ronmental impacts (Bowen, 2000; Hoffman, 1999; Morris, 1997). In contrast, other industries, particu-larly newer manufacturing industries and the service sector, have significantly lower environmental impacts and are associated with fewer visible envi-ronmental issues. Therefore, companies in these industries are expected to be subject to significantly less stakeholder pressure regarding their environ-mental performance, and so would be expected to display a lesser degree of disclosure activism. Hence, the discussion above leads us to the hypothesis that:
H2: There is a positive significant relationship between industry environmental sensitivity and CSR disclosure.

\section{Profitability}

There are several studies, mainly based on the stakeholder theory, that suppose a positive relationship between social disclosure policy and profitability (Belkaoui and Karpik, 1989; Cowen et al., 1987; Ismail and Chandler, 2005; Roberts, 1992; Ullmann, 1985), although it should be noted that the empirical results do not always confirm that positive relationship (Archel, 2003; Brammer and Pavelin, 2008; Carmona and Carrasco, 1988; Garc1'a-Ayuso and Larrinaga, 2003; Moneva and Llena, 1996; Roberts, 1992). According to Belkaoui and Karpik (1989), the underlying cause of a positive relationship between social disclosure policy and profitability is management's knowledge. A management that has the knowledge to make a company profitable also has the knowledge and understanding of social responsibility, which leads to more social and environmental disclosures. In the context of the agency and political cost theories, Giner (1997) points out that management in very profitable corporations provide more detailed information in order to support their own position and compensation. $\mathrm{Ng}$ and Koh (1994) point to the fact that profitable corporations are more exposed to political pressure and public scrutiny, and therefore use more self-regulating mechanisms, for instance voluntary disclosure of information, in order to avoid regulation. The most obvious and explicit explanation might be that profitable corporations have the necessary economical means - the so-called organizational slack (Cowen et al., 1987; Hackston and Milne, 1996; Pirsch et al., 2007). In a corporation with less economical resources, management will probably focus on activities that have a more direct effect on the corporation's earnings than the production of social and environmental disclosures (Roberts, 1992; Ullmann, 1985). However, from a legitimacy theory perspective, profitability can be regarded to be either positively or negatively related to CSR disclosure (Neu et al., 1998). As these authors point out, where the organization is 
profitable, environmental disclosures would, for those stakeholders who value the environment, give confirmation that profit has not been at the expense of the environment. Conversely, in periods of relative unprofitability, these same disclosures might be either directed at convincing financial stakeholders that current environmental investments will result in long-term competitive advantages or at distracting attention from the financial results. Thus, we do not make any a priori assumption about the sign of the association between CSR disclosure and profitability.

H3: There is a significant relationship between profitability and CSR disclosure.

\section{Ownership structure}

The degree to which ownership of company stock is concentrated in the hands of a few large investors or dispersed among many has been proposed as an influence on disclosure policy (Roberts, 1992; Ullmann, 1985). Opportunistic management behavior and conflict of interests between agents and principals are more likely to occur in corporations with more dispersed ownership. In a widely held company, voluntary disclosure can act as a bonding and monitoring tool reducing agency conflicts between managers and shareholders (Jensen and Meckling, 1976). Evidence suggests that ownership dispersion across many investors contributes to increased pressure for voluntary disclosure (Cullen and Christopher, 2002; Ullmann, 1985). Hence, corporations with many owners are in general expected to disclose more information than corporations with concentrated ownership in order to reduce information asymmetries between the organization and its shareholders (Prencipe, 2004). Firms whose shares are widely held are more likely to improve their financial reporting policy by using their CSR disclosure in order to reduce these asymmetries. On the contrary, firms with a concentrated ownership structure are less motivated to disclose additional information on their CSR, insofar as the shareholders of these firms can obtain information directly from the firm. Reinforcing the previous arguments, Brammer and Pavelin (2008) evidence, in the context of environmental information, that having greater ownership concentration makes a firm less likely to disclose an environmental policy. Thus, we hypothesize that:

\section{H4: There is a negative relationship between CSR disclosure and concentrated ownership.}

\section{International listing}

According to Cooke (1989), when a firm is listed on a foreign exchange, it will disclose more detailed information since it may need to observe the disclosure rules of two or more stock exchanges, and it will attract more analyst coverage. In this respect, disclosure serves to limit the monitoring and agency costs resulting from the existence of a greater number of shareholders. Reinforcing the previous arguments, Singhvi and Desai (1971), Cooke (1989), Hossain et al. (1994, 1995) and Robb et al. (2001) find international listing status to be a significant determinant of the voluntary disclosure level. Thus, we hypothesize that:

H5: There is a positive significant relationship between CSR disclosure and international listing.

\section{Media exposure}

Legitimacy theory research extends to examining the role media coverage plays in increasing the public policy pressures faced by companies (Patten, 2002b). The total amount of media coverage raises the firm's visibility, inviting further public attention and scrutiny. The media can play an important role in mobilizing social movements such as environmental interest groups. In doing so, it becomes part of the institution-building process, shaping the norms of acceptable and legitimate CSR practices. According to Simon (1992), the media is the main source of environmental information. The media not only plays a passive role in shaping institutional norms, but also a more active one by choosing the stories worth reporting and framing them to reflect editorial values. Empirical studies have shown that the media has been particularly influential on corporate envi- 
ronmental responses (Bansal and Clelland, 2004; Bansal and Roth, 2000; Bowen, 2000; Henriques and Sadorsky, 1996). Based on these arguments, the following hypothesis is tested:

H6: There is a positive significant relationship between CSR disclosure and media exposure.

\section{Leverage}

Within the context of the agency theory, Jensen and Meckling (1976) argue that more highly leveraged firms disclose voluntary information in order to reduce their agency costs and, as a result, their cost of capital. However, Brammer and Pavelin (2008) sustain that a low degree of leverage ensures that creditor stakeholders will exert less pressure to constrain managers' discretion over CSR activities, which are only indirectly linked to the financial success of the firm. Purushothaman et al. (2000) also predict a negative relationship between leverage and CSR disclosure in that companies with high leverage may have closer relationships with their creditors and use other means to disclose social responsibility information. Thus, we do not make any a priori assumption about the sign of the association between CSR disclosure and leverage. The following hypothesis is thus tested:

H7: There is a significant relationship between CSR disclosure and leverage. ${ }^{1}$

\section{Data and method of estimation}

\section{CSR ratings: the dependent variable}

Our data on CSR disclosure ratings come from the Observatory on corporate social responsibility (OCSR). This is an association integrated by fourteen organizations that represent civil society, NGOs, trade unions, and consumer organizations. It is a network that fosters participation and cooperation between social organizations that, from different points of view, are interested in CSR. The OCSR issues each year a very exhaustive report on CSR disclosures by Spanish listed firms included in the
IBEX35 index, which comprises the largest 35 firms in terms of market capitalization. Each of the covered firms is assigned a numerical rating (ranging from 0 to 4 in a continuous scale) based on the adherence of their CSR disclosures to the following rules/recommendations: (a) Global Reporting Initiative (GRI)'s Guidelines (G2 and G3); (b) United Nations Norms on the Responsibilities of Transnational Corporations and Other Business Enterprises with Regard to Human Rights [U.N. Doc. E/ CN.4/Sub.2/2003/38/Rev.2 (2003)]; (c) AA1000 Accountability Principles issued by the Institute of Social and Ethical AccountAbility); (d) New Economics Foundation (NEF) Principles and (e) Corporate Governance recommendations issued by the Spanish stock market regulator and, in the case of US cross-listed firms, the Sarbanes-Oxley Law. We focus on the following three ratings reported by the OCSR:

a) Total CSR score (TCSR), which captures the overall adherence of a firm's CSR disclosure practices to the previous rules/recommendations;

b) CSR Content Rating (CR), which evaluates the concordance of the information provided by a firm to the recommendations reported in:

- GRI Performance Indicators section related to:

- economic perfomance

- environmental performance

- social performance

- human rights

- labor practices and decent work

- society

- product responsibility

- United Nations Norms on the Responsibilities of Transnational Corporations and Other Business Enterprises with Regard to Human Rights (especially in the fields of protection of consumer rights and corruption);

c) CSR Management Systems Rating (MSR), which evaluates the adherence of the processes and management systems in the CSR area to those outlined in: 
- GRI's Profile section.

- GRI's Principles (relevance/materiality, stakeholder inclusiveness, reliability/auditability, neutrality, sustainability context, accuracy, comparability, clarity, completeness, timeliness, transparency).

- AA1000 Principles (completeness, materiality, regularity and timeliness, quality assurance, information quality, embeddedness, continuous improvement, accessibility).

- NEF's Principles (inclusivity, completeness, comparability, embeddedness, disclosure, external verification, continuous improvement, evolution).

\section{Explanatory variables measurement}

\section{Media exposure}

To develop a measure of the companies' media exposure, the number of articles in the two main Spanish business newspapers ('Expansión' and 'Actualidad Económica') was counted. Company exposure was measured by using the search facilities present on the web pages of those newspapers for each of the 2 years analyzed (2005 and 2006). ${ }^{2}$

\section{Profitability}

In order to measure corporate performance, either accounting- or market-based measures can be used. In contrast with accounting-based measures, marketbased measures are less subject to bias by managerial manipulation and they do not rely on past performance (McGuire et al., 1988). However, they are based on investors' viewpoints on company performance, thus ignoring other important stakeholder groups. This is the main reason for adopting an accounting-based variable in our paper, such as return on assets (ROA) (Belkaoui and Karpik, 1989; Bewley and Li, 2000; Brammer and Pavelin, 2008; Cormier et al., 2004; Patten, 1991).

\section{Industry sensitivity}

In this study, "more sensitive" industries are considered to be those with more risk of being criticized in CSR matters because of their activities involving higher risk of environmental impact. Based on prior literature, the following "more sensitive" sectors are identified: mining, oil and gas, chemicals, forestry and paper, steel and other metals, electricity, gas distribution, and water. All others are considered as "less sensitive." A one/zero variable is used to designate companies from these industries: one if the company is from a more sensitive industry and zero if it is from a less sensitive industry.

\section{International listing}

International listing is measured by the number of foreing stock markets in which the firm is listed.

\section{Company size}

Following prior research, size is measured as the natural logarithm of market capitalization. ${ }^{3}$

\section{Ownership concentration}

This variable is measured from data concerning significant shareholdings from 2005 and 2006 annual reports of the sample companies. Thus, if a firm has a majority shareholder we assign it a value of 1 and if not it is assigned a zero value.

\section{Leverage}

This variable is measured as long-term debt/book value of equity (Cormier et al., 2005). ${ }^{4}$

Sample

Our sample comprises those firms covered by the OCSR report, i.e., Spanish firms listed on the Madrid Stock Exchange and included in the IBEX35 index. However, due to the fact that most of our explanatory variables are based on accounting data, we have excluded financial firms because of the particular characteristics of their accounting system. Moreover, since all firms under study present consolidated accounts and they had to be prepared in accordance with International Financial Reporting Standards (IFRS) issued by the IASB from 2005 onward - Regulation 1606/2002 of the European Commission - we have chosen fiscal years 2005 and 2006 so as to ensure comparability in accounting data. After eliminating firms with extreme values for some of the explanatory variables, the final sample comprises 46 observations. ${ }^{5}$ 


\section{Empirical models}

The statistical analysis conducted in this study includes the use of linear regression models to analyze the relationship between CSR ratings and each of the influencing factors referred to in the previous section. The three estimated models differ in their dependent variables: Total CSR (TSCR), CSR Content Rating (CR), and CSR Management Systems Rating (MSR). The approach adopted in the empirical analysis is summarized by the following general form of the models:

$$
\begin{aligned}
\operatorname{CSR}_{\text {rating }}= & \beta_{0}+\beta_{1} \mathrm{ME}_{i}+\beta_{2} \mathrm{IL}_{i}+\beta_{3} \mathrm{IND}_{i} \\
& +\beta_{4} \mathrm{SIZE}_{i}+\beta_{5} \mathrm{OWNER}_{i} \\
& +\beta_{6} \mathrm{ROA}_{i}+\beta_{7} \mathrm{LEV}_{i}+\varepsilon_{i}
\end{aligned}
$$

where, ME: media exposure; IL: International listing; IND: Industry environmental sensitivity; SIZE: Firm's size; OWNER: Ownership concentration; ROA: Profitability (return on assets); LEV: Leverage.

\section{Results}

Table I reports the descriptive statistics of the dependent and independent variables considered in our study. It can be seen a high variability in CSR practices across Spanish listed firms, as the total CSR rating varies from 0.170 to 1.940 . As the maximum value is 4 , we can assert that the degree of information on CSR by Spanish listed firms is still rather low.

Table II reports the correlation coefficients among our set of independent variables. It can be seen that some correlations are statistically significant at a $1 \%$ level, such as those between size and media exposure $(\rho=0.599)$, industry and leverage $(\rho=-0.465)$ and leverage and return on assets $(\rho=-0.526)$. However, none of the variance inflation factors (VIFs) - not reported - exceed the critical value of 10 . Thus, it can be said that multicollinearity is not a serious problem in our study.

Table III reports the mean values of the explanatory variables under analysis across the several CSR disclosure ratings for both firms with a rating higher than the median and those with a rating lower than the median. To test the statistical significance of the mean differences in the explanatory variables between both groups of firms, we perform a $t$-test (if the variable is normally distributed) and a Wilcoxon signed-rank test (if the variable is non-normally distributed). It can be observed that firms with a total CSR rating higher than the median operate in a more environmentally sensitive industry $(p=0.008)$, have a higher media exposure $(p=0.000)$, a larger size $(p=0.010)$, and a less concentrated ownership $(p=0.004)$, as compared to those firms with a CSR rating lower than the median. However, although firms disclosing more on CSR activities are listed on a higher number of foreign stock markets, have a lower leverage and are more profitable, these differences are not significantly different, at a 5\% level, between both groups of firms. It should be noted that the results are generally consistent across the other two CSR ratings.

Table IV reports the results of regressing the explanatory factors on the various CSR ratings. The first rows of each panel present the results of regressing the explanatory factors one by one on the CSR ratings, while the last row combines all the explanatory variables together. When considered individually, it can be seen that firms with higher CSR ratings present a statistically significant larger size, and a higher media exposure. Also, firms with higher CSR ratings belong to more environmentally sensitive industries, and are listed in a higher number of foreign stock markets. As regards ownership structure, firms with higher CSR ratings have a less concentrated ownership. However, neither ROA nor leverage seem to explain differences in CSR disclosure practices between Spanish listed firms. In terms of $R^{2}$, the most influential variable for explaining firms' variation in total CSR ratings is media exposure $\left(R^{2}=0.338\right)$, followed by size $\left(R^{2}=0.186\right)$ and industry $\left(R^{2}=0.164\right)$. When pulling all the explanatory factors together, they explain between $42.9 \%$ and $47.5 \%$ of the variation of the several CSR ratings. The variables that are statistically significant for all the CSR ratings are those related to public or social visibility (i.e., size, media exposure, and industry environmental sensitivity). According to these results, it seems that the legitimacy theory is the most relevant theory for explaining CSR disclosure practices of Spanish listed firms. Thus, Spanish firms report on CSR activities in order to respond to public pressures and build or 
TABLE I

Descriptive statistics for the dependent and independent variables

\begin{tabular}{|c|c|c|c|c|c|}
\hline Variable & Mean & Median & SD & Minimun & Maximum \\
\hline \multicolumn{6}{|c|}{ Dependent variables } \\
\hline TCSR & 1.150 & 1.245 & 0.485 & 0.170 & 1.940 \\
\hline $\mathrm{CR}$ & 0.835 & 0.855 & 0.491 & 0.020 & 1.670 \\
\hline MSR & 1.194 & 1.315 & 0.614 & 0.020 & 2.210 \\
\hline \multicolumn{6}{|c|}{ Independent variables } \\
\hline $\mathrm{ME}$ & 69.369 & 43.000 & 57.047 & 6.000 & 268.000 \\
\hline IL & 5.783 & 6.000 & 3.039 & 1.000 & 12.000 \\
\hline IND & 0.456 & 0.000 & 0.504 & 0.000 & 1.000 \\
\hline SIZE & 15.935 & 15.965 & 0.936 & 14.280 & 18.190 \\
\hline OWNER & 0.283 & 0.000 & 0.455 & 0.000 & 1.000 \\
\hline $\mathrm{ROA}$ & 0.052 & 0.047 & 0.033 & 0.003 & 0.174 \\
\hline LEV & 3.804 & 3.032 & 2.769 & 0.659 & 13.789 \\
\hline
\end{tabular}

Notes: TCSR: Total corporate social responsibility index; CR: CSR Content rating; MSI: CSR Management Systems rating; ME: Media exposure; IL: International listing; IND: Industry environmental sensitivity; SIZE: Firm's size; OWNER: Ownership concentration; ROA: Return on assets; LEV: Long-term debt/book value of equity. See variables measurement in the text.

TABLE II

Correlation coefficients among independent variables

\begin{tabular}{|c|c|c|c|c|c|c|c|}
\hline & ME & IL & IND & SIZE & OWNER & ROA & LEV \\
\hline ME & & $0.345^{\star}$ & $0.370^{\star}$ & $0.599 \star \star$ & $-0.307^{\star}$ & 0.018 & -0.071 \\
\hline IL & & & -0.021 & $0.325^{\star}$ & 0.045 & 0.062 & 0.076 \\
\hline IND & & & & 0.063 & $-0.381 \star \star$ & 0.035 & $-0.465^{\star \star}$ \\
\hline SIZE & & & & & -0.093 & $0.317^{\star}$ & 0.059 \\
\hline OWNER & & & & & & 0.043 & $0.302^{\star}$ \\
\hline ROA & & & & & & & $-0.526 \star \star$ \\
\hline
\end{tabular}

Notes: ME: Media exposure; IL: International listing; IND: Industry environmental sensitivity; SIZE: Firm's size; OWNER: Ownership concentration; ROA: Return on assets; LEV: Long-term debt/book value of equity. See variables measurement in the text.

$\star$ Significant at a $5 \%$ level, $\star \star$ Significant at a $1 \%$ level.

sustain corporate legitimacy. In this regard, CSR disclosure can be viewed as a constructed image or symbolic impression of itself that a firm is conveying to the outside world to control its political or economic position (Neu et al., 1998).

\section{Concluding remarks}

The goal of this study is to analyze whether a number of firm and industry characteristics, as well as media exposure, are potential determinants of
CSR disclosure practices by Spanish listed firms. Empirical studies have shown that CSR disclosure activism varies across companies, industries, and time (Gray et al., 1995, 2001; Hackston and Milne, 1996). They have also shown this behavior to be importantly and systematically determined by a variety of firm and industry characteristics that influence the relative costs and benefits of disclosing such information (Belkaoui and Karpik, 1989; Cormier and Magnan, 2003; Cormier et al., 2005; Hackston and Milne, 1996; Patten, 2002a, b). 


\section{TABLE III}

Differences in the value of the explanatory variables between firms with higher and lower CSR ratings

\begin{tabular}{|c|c|c|c|}
\hline Variables & Firms with TCSR $>$ median & Firms with TCSR $<$ median & Difference ( $p$-value in parentheses) \\
\hline \multicolumn{4}{|c|}{ Panel A: Total CSR rating (TCSR) } \\
\hline ME & 98.522 & 40.217 & $58.305(0.000)$ \\
\hline IL & 6.304 & 5.261 & $1.043(0.076)$ \\
\hline IND & 0.652 & 0.261 & $0.391(0.008)$ \\
\hline SIZE & 16.287 & 15.583 & $0.704(0.010)$ \\
\hline OWNER & 0.087 & 0.478 & $-0.391(0.004)$ \\
\hline ROA & 0.057 & 0.047 & $0.010(0.095)$ \\
\hline LEV & 3.016 & 4.592 & $-1.576(0.191)$ \\
\hline
\end{tabular}

\begin{tabular}{lcrr}
\hline Variables & Firms with CR $>$ median & Firms with CR $<$ median & Difference $(p$-value in parentheses $)$ \\
\hline Panel B: CSR Content Rating (CR) & & $65.783(0.000)$ \\
ME & 102.261 & 36.478 & $1.913(0.031)$ \\
IL & 6.739 & 4.826 & $0.565(0.000)$ \\
IND & 0.739 & 0.174 & $0.734(0.007)$ \\
SIZE & 16.302 & 15.568 & $-0.131(0.331)$ \\
OWNER & 0.217 & 0.348 & $0.006(0.286)$ \\
ROA & 0.055 & 0.049 & $-0.671(0.448)$ \\
LEV & 3.468 & 4.139 & $(0.448)$ \\
\hline
\end{tabular}

Variables $\quad$ Firms with MSR $>$ median $\quad$ Firms with MSR $<$ median $\quad$ Difference $(p$-value in parentheses $)$

Panel C: CSR Management Systems Rating (MSR)

\begin{tabular}{|c|c|c|c|}
\hline $\mathrm{ME}$ & 99.087 & 39.652 & $59.435(0.000)$ \\
\hline IL & 6.304 & 5.261 & $1.043(0.250)$ \\
\hline IND & 0.696 & 0.217 & $0.479(0.001)$ \\
\hline SIZE & 16.274 & 15.596 & $0.678(0.013)$ \\
\hline OWNER & 0.087 & 0.478 & $-0.391(0.004)$ \\
\hline ROA & 0.057 & 0.047 & $0.010(0.062)$ \\
\hline LEV & 2.742 & 4.865 & $-2.123(0.063)$ \\
\hline
\end{tabular}

Notes: ME: Media exposure; IL: International listing; IND: Industry environmental sensitivity; SIZE: Firm's size; OWNER: Ownership concentration; ROA: Return on assets; LEV: Long-term debt/book value of equity. See variables measurement in the text.

Our findings evidence that firms with higher CSR ratings present a statistically significant larger size and a higher media exposure, and belong to more environmentally sensitive industries, as compared to firms with lower CSR ratings. However, neither profitability nor leverage seem to explain differences in CSR disclosure practices between Spanish listed firms. The most influential variable for explaining firms' variation in CSR ratings is media exposure, followed by size and industry. Therefore, it seems that the legitimacy theory, as captured by those variables related to public or social visibility, is the most relevant theory for explaining CSR disclosure practices of Spanish listed firms. Thus, Spanish firms report on CSR activities mainly to act and be seen acting within the bounds of what is considered acceptable according to the expectations of stakeholders on how their operations should be conducted.

Moreover, the results of this study suggest that factors which influence CSR practices of Spanish listed companies are not significantly different than those which influence CSR of companies in other 


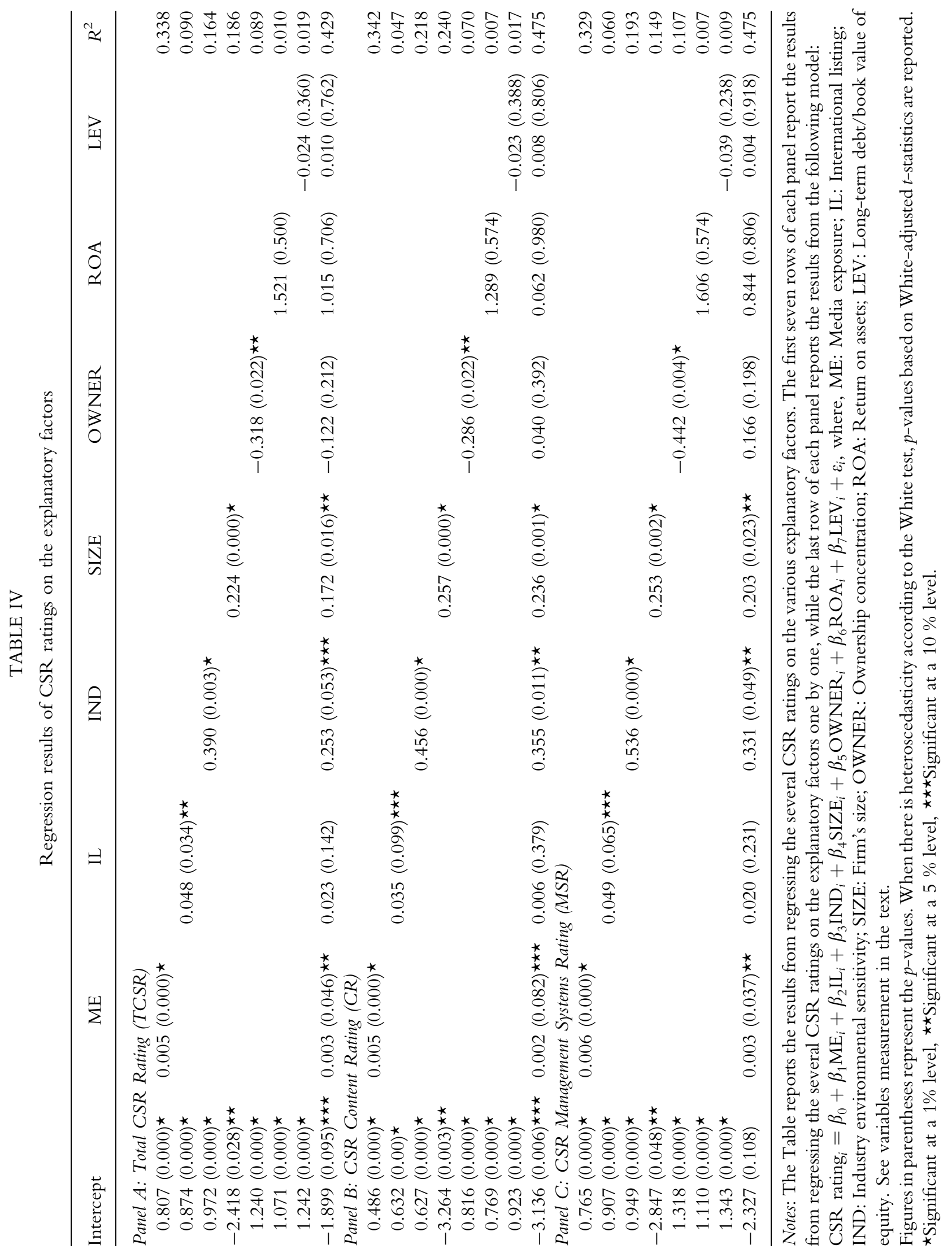


environments. This is consistent with the results of Cormier and Magnan (2003), which lead them to suggest that the similitude in the way in which disclosure strategies are determined, irrespective of a given country's socio-cultural environment, is "an illustration of the strong impact of globalised stock markets on fostering convergence in corporate practices" (2003, p. 58).

\section{Notes}

1 Results are similar if a market-based measure of risk, such as beta, is used instead of leverage in the regression models.

2 Most of the literature in this area assumes a contemporary relationship between media exposure and CSR disclosure (e.g., Bansal and Clelland, 2004; Cormier et al., 2004, 2005). But this relationship could be prob-ably delayed, i.e., more media coverage one year could result in more CSR disclosure in future years. In order to test this delayed relationship, I have re-estimated the models introducing the variable 'Media exposure' (ME) with a one-year lag $\left(\mathrm{ME}_{\mathrm{t}-1}\right)$. However, this lagged var-iable has not turned out to be statistically significant. This result could be due to the high correlation $(\rho=0.832)$ between media exposure in year $t\left(\mathrm{ME}_{\mathrm{t}}\right)$ and year $t-1\left(\mathrm{ME}_{\mathrm{t}-1}\right)$, i.e., those firms with a high media coverage in one period tend also to be highly followed by media in the following period.

3 Results are similar is size is proxied by the log of total assets.

4 If leverage is measured by the ratio total debt/total assets the results remain unchanged.

5 Taking every year as a separate observation may aggravate the problem of extreme values. In order to test the existence of extreme observations that could unduly influence our results, I have applied the most usual diagnostic tests for detecting outliers, such as the studentized residuals, the Cook's D, DF-betas, and least absolute values (LAV). These additional tests indicate that the main results of our study are not driven by outliers.

\section{Acknowledgment}

This work is part of the research project ECO200806238-C02-01/ECON funded by the Spanish Ministry of Education and Science and ERDF.

\section{References}

Adams, C. A., W. Y. Hill and C. B. Roberts: 1998, 'Corporate Social Reporting Practices in Western Europe: Legitimating Corporate Behaviour', The British Accounting Review 30(1), 1-21. doi:10.1006/ bare.1997.0060.

Adrem, A. H.: 1999, Essays on Disclosure Practices in Sweden - Causes and Effects (Lund University Press).

Archel, P.: 2003, 'La divulgación de la información social y medioambiental de la gran empresa española en el período 1994-1998: situación actual y perspectivas', Revista Española de Financiación y Contabilidad 117, 571-601.

Archel, P. and F. Lizarraga: 2001, 'Algunos determinantes de la información medioambiental divulgada por las empresas españolas cotizadas', Revista de Contabilidad 4(7), 129-153.

Bansal, P. and I. Clelland: 2004, 'Talking Trash: Legitimacy, Impression Management and Unsystematic Risk in the Context of the Natural Environment', Academy of Management Journal 47(1), 93-103.

Bansal, P. and K. Roth: 2000, 'Why Companies Go Green: A Model of Ecological Responsiveness', Academy of Management Journal 43(4), 717-736. doi:10.2307/ 1556363.

Belkaoui, A. and P. G. Karpik: 1989, 'Determinants of the Corporate Decision to Disclose Social Information', Accounting, Auditing \& Accountability Journal 2(1), 36-51. doi:10.1108/09513578910132240.

Bewley, K. and Y. Li: 2000, 'Disclosure of Environmental Information by Canadian Manufacturing Companies: A Voluntary Disclosure Perspective', Advances in Environmental Accounting and Management 1, 201-226. doi:10.1016/S1479-3598(00)01011-6.

Blacconiere, W. G. and W. D. Northcut: 1997, 'Environmental Information and Market Reactions to Environmental Legislation', Journal of Accounting, Auditing \& Finance 12(Spring), 149-178.

Blacconiere, W. G. and D. M. Patten: 1994, 'Environmental Disclosures, Regulatory Costs and Changes in Firm Value', Journal of Accounting and Economics 18(3), 357-377. doi:10.1016/0165-4101(94)90026-4.

Bowen, F.: 2000, 'Environmental Visibility: A Trigger of Green Organizational Response?', Business Strategy and the Environment 9(2), 92-107. doi:10.1002/(SICI)10990836(200003/04)9:2\&lt;92::AID-BSE230\&gt;3.0.CO; $2-\mathrm{X}$.

Brammer, S. and S. Pavelin: 2008, 'Factors Influencing the Quality of Corporate Environmental Disclosure', Business Strategy and the Environment 17, 120-136. doi:10.1002/bse.506. 
Brown, N. and C. Deegan: 1998, 'The Public Disclosure of Environmental Performance Information - A Dual Test of Media Agenda Setting Theory and Legitimacy Theory', Accounting and Business Review 29(1), 21-41.

Campbell, D. J.: 2000, 'Legitimacy Theory or Managerial Reality Construction? Corporate Social Disclosure in Marks and Spencer, Plc Corporate Reports 1969-1997', Accounting Forum 24(1), 80-100. doi:10.1111/1467-6303.00030.

Carmona, S. and F. Carrasco: 1988, 'Información de contenido social y estados contables: Una aproximación empírica y algunas consideraciones teóricas', Actualidad Financiera noviembre, 2175-2192.

CEC: 2001, Green Paper: Promoting a European Framework for Corporate Social Responsibility (COM), 366 final.

Clarke, J. and M. Gibson-Sweet: 1999, 'The Use of Corporate Social Disclosures in the Management of Reputation and Legitimacy: A Cross Sectoral Analysis of UK Top 100 Companies', Business Ethics. European Review (Chichester, England) 8(1), 5-13.

Cooke, T. E.: 1989, 'Voluntary Corporate Disclosure by Swedish Companies', Journal of International Financial Management and Accounting 1(2), 171-195. doi:10.1111/ j.1467-646X.1989.tb00009.x.

Cormier, D. and M. Magnan: 2003, 'Environmental Reporting Management: A Continental European Perspective', Journal of Accounting and Public Policy 22(1), 43-62. doi:10.1016/S0278-4254(02)00085-6.

Cormier, D., I. M. Gordon and M. Magnan: 2004, 'Corporate Environmental Disclosure: Contrasting Management's Perceptions with Reality', Journal of Business Ethics 49(2), 143-165. doi:10.1023/B:BUSI.0000015 844.86206.b9.

Cormier, D., M. Magnan and B. Van Velthoven: 2005, 'Environmental Disclosure Quality in Large German Companies: Economic Incentives, Public Pressures or Institutional Conditions?', European Accounting Review 14(1), 3-39. doi:10.1080/0963818042000339617.

Cowen, S. S., L. B. Ferreri and L. D. Parker: 1987, 'The Impact of Corporate Characteristics on Social Responsibility Disclosure: A Typology and FrequencyBased Analysis', Accounting, Organizations and Society 12(2), 111-122. doi:10.1016/0361-3682(87)90001-8.

Cullen, L. and T. Christopher: 2002, 'Governance Disclosures and Firm Characteristics of Listed Australian Mining Companies', International Journal of Business Studies 10(1), 37-58.

Deegan, C.: 2002, 'The Legitimising Effect of Social and Environmental Disclosures - A Theoretical Foundation', Accounting, Auditing \& Accountability Journal 15(3), 282-311. doi:10.1108/09513570210435852.
Deegan, C. and B. Gordon: 1996, 'A Study of the Environmental Disclosure Practices of Australian Corporations', Accounting and Business Review 26(3), 187-199.

Deegan, C. and M. Rankin: 1996, 'Do Australian Companies Report Environmental News Objectively? An Analysis of Environmental Disclosures by Firms Prosecuted Successfully by the Environmental Protection Authority', Accounting, Auditing \& Accountability Journal 9(2), 50-67. doi:10.1108/09513579610116 358.

DiMaggio, P. J. and W. W. Powell: 1983, 'The Iron Cage Revisited: Institutional Isomorphism and Collective Rationality in Organizational Fields', American Sociological Review 48, 147-160. doi:10.2307/2095101.

Dowling, J. and J. Pfeffer: 1975, 'Organisational Legitimacy: Social Values and Organisational Behaviour', Pacific Sociological Review 18(1), 122-136.

García-Ayuso, M. and C. Larrinaga: 2003, 'Environmental Disclosure in Spain: Corporate Characteristics and Media Exposure', Revista Española de Financiación y Contabilidad 115, 184-214.

Giner, B.: 1997, 'The Influence of Company Characteristics and Accounting Regulation on Information Disclosed by Spanish Firms', European Accounting Review 6(1), 45-68. doi:10.1080/096381897336863.

Godfrey, P. C. and N. W. Hatch: 2007, 'Researching Corporate Social Responsibility: An Agenda for the 21st Century', Journal of Business Ethics 70(1), 87-98. doi:10.1007/s10551-006-9080-y.

Graham, A., J. Maher and W. D. Northcut: 2000, 'Environmental Liability Information and Bond Ratings', Journal of Accounting, Auditing \& Finance 15(2), 93-116.

Gray, R., R. Kouhy and S. Lavers: 1995, 'Corporate Social and Environmental Reporting: A Review of the Literature and a Longitudinal Study of UK Disclosure', Accounting, Auditing \& Accountability Journal 8(2), 47-77. doi:10.1108/09513579510146996.

Gray, R. H., D. Owen and C. Adams: 1996, Accounting and Accountability (Prentice Hall, Hemel Hempstead).

Gray, R., M. Javad, D. M. Power and C. D. Sinclair: 2001, 'Social and Environmental Disclosure and Corporate Characteristics: A Research Note and Extension', Journal of Business Finance \& Accounting 28(3/4), 327-356. doi:10.1111/1468-5957.00376.

Guthrie, J. and L. Parker: 1989, 'Corporate Social Reporting: A Rebuttal of Legitimacy Theory', Accounting and Business Review 19(3), 343-352.

Hackston, D. and M. J. Milne: 1996, 'Some Determinants of Social and Environmental Disclosures in New Zealand Companies', Accounting, Auditing \& Accountability Journal 9(1), 77-108. doi:10.1108/095135796 10109987. 
Hamid, F. Z. A.: 2004, 'Corporate Social Disclosure by Banks and Finance Companies: Malaysian Evidence', Corporate Ownership \& Control 1(4), 118-130.

Haniffa, R. M. and T. E. Cooke: 2005, 'The Impact of Culture and Governance on Corporate Social Reporting', Journal of Accounting and Public Policy 24(5), 391-430. doi:10.1016/j.jaccpubpol.2005.06.001.

Henriques, I. and P. Sadorsky: 1996, 'The Role of Information in Coordinating Environmental Issues', in Academy of Management Best Paper Proceedings (Cincinnati, $\mathrm{OH})$, pp. 1-30.

Hoffman, A. J.: 1999, 'Institutional Evolution and Change: Environmentalism and the U.S. Chemical Industry', Management Journal 42(4), 351-371.

Hooghiemstra, R.: 2000, 'Corporate Communication and Impression Management: New Perspectives Why Companies Engage in Corporate Social Reporting', Journal of Business Ethics 27(1/2), 55-68. doi:10.1023/ A:1006400707757.

Hossain, M., L. M. Tan and M. Adams: 1994, 'Voluntary Disclosure in an Emerging Capital Market: Some Empirical Evidence from Companies Listed on Kuala Lumpur Stock Exchange', The International Journal of Accounting 29(4), 334-351.

Hossain, M., M. H. B. Perera and A. R. Rahman: 1995, 'Voluntary Disclosure in the Annual Reports of New Zealand Companies', Journal of International Financial Management and Accounting 6(1), 69-87. doi:10.1111/ j. 1467-646X.1995.tb00050.x.

Hutchings, G. and D. W. Taylor: 2000, 'The IntraIndustry Capital Market and Corporate Reporting Effects of the BHP Ok Tedi Environmental Event', Asian Review of Accounting 8(Special Issue), 33-54.

Ismail, K. N. and R. Chandler: 2005, 'Disclosure in the Quarterly Reports of Malaysian Companies', Financial Reporting. Regulation and Governance 4(1), 1-26.

Jenkins, H. M. and N. Yakovleva: 2006, 'Corporate Social Responsibility in the Mining Industry: Exploring Trends in Social and Environmental Disclosure', Journal of Cleaner Production 14(3-4), 271-284. doi:10.1016/j.jclepro.2004.10.004.

Jennings, P. D. and P. A. Zandbergen: 1995, 'Ecologically Sustainable Organizations: An Institutional Approach', Academy of Management Review 20(4), 1015-1052. doi:10.2307/258964.

Jensen, M. C. and W. H. Meckling: 1976, 'Theory of the Firm: Managerial Behavior, Agency Costs and Ownership Structure', Journal of Financial Economics 3, 305360. doi:10.1016/0304-405X(76)90026-X.

Knox, S., S. Maklan and P. French: 2006, 'Corporate Social Responsibility: Exploring Stakeholder Relationships and Programme Reporting Across Leading
FTSE Companies', Journal of Business Ethics 61(1), 728. doi:10.1007/s10551-005-0303-4.

Kolk, A.: 2003, 'Trends in Sustainability Reporting by the Fortune Global 250', Business Strategy and the

Environment 12(5), 279-291. doi:10.1002/bse.370. Line, M., H. Hawley and R. Krut: 2002, 'Development in Global Environmental and Social Reporting', Corporate Environmental Strategy 9(1), 69-78. doi:10.1016/S10667938(01)00159-2.

McGuire, J. B., A. Sundgren and T. Schneeweis: 1988, 'Corporate Social Responsibility and Firm Financial Performance', Academy of Management Journal 31(4), 854-872. doi:10.2307/256342.

Meyer, J. W. and B. Rowan: 1977, 'Institutionalized Organizations: Formal Structure as Myth and Ceremony', American Journal of Sociology 83, 340-363. doi:10.1086/226550.

Milne, M. J.: 2002, 'Positive Accounting Theory, Political Costs and Social Disclosure Analyses: A Critical Look', Critical Perspectives on Accounting 13(3), 369-395. doi:10.1006/cpac.2001.0509.

Moneva, J. M. and F. Llena: 1996, 'Análisis de la información sobre responsabilidad social en las empresas industriales que cotizan en Bolsa', Revista Española de Financiación y Contabilidad $\mathbf{X X V ( 8 7 ) , ~}$ 361-401.

Moneva, J. M. and F. Llena: 2000, 'Environmental Disclosures in the Annual Reports of Large Companies in Spain', European Accounting Review 9(1), 7-29. doi:10.1080/096381800407923.

Morris, S.: 1997, 'Environmental Pollution and Competitive Advantage: An Exploratory Study of U.S. Industrial-Goods Manufacturers', in Academy of Management Conference Proceedings, 1997 (Academy of Management, New York).

Nasi, J., S. Nasi, N. Phillips and S. Zyglidopoulos: 1997, 'The Evolution of Corporate Social Responsiveness', Business \& Society 36(3), 296-321. doi:10.1177/ 000765039703600305.

Ness, K. and A. Mirza: 1991, 'Corporate Social Disclosure: A Note on the Test of Agency Theory', The British Accounting Review 23, 211-217. doi:10.1016/ 0890-8389(91)90081-C.

Neu, D., H. Warsame and K. Pedwell: 1998, 'Managing Public Impressions: Environmental Disclosures in Annual Reports', Accounting, Organizations and Society 23(3), 265-282. doi:10.1016/S0361-3682(97) 00008-1.

Ng, E. J. and H. C. Koh: 1994, 'An Agency Theory and Profit Analytic Approach to Corporate Non-Mandatory Disclosure Compliance', Asia-Pacific Journal of Accounting 1(1), 29-44. 
Oliver, C.: 1991, 'Strategic Responses to Institutional Processes', Academy of Management Review 16(1), 145179. doi:10.2307/258610.

Patten, D. M.: 1991, 'Exposure, Legitimacy, and Social Disclosure', Journal of Accounting and Public Policy 10(4), 297-308. doi:10.1016/0278-4254(91)90003-3.

Patten, D. M.: 2002a, 'Give or Take on the Internet: An Examination of the Disclosure Practices of Insurance Firm Web Innovators', Journal of Business Ethics 36(3), 247-259. doi:10.1023/A:1014009229437.

Patten, D. M.: 2002b, 'Media Exposure, Public Policy Pressure, and Environmental Disclosure: An Examination of the Impact of Tri Data Availability', Accounting Forum 26(2), 152-171. doi:10.1111/14676303.t01-1-00007.

Perrow, C.: 1970, Organizational Analysis: A Sociological View (Wadsworth, Belmont, CA).

Pirsch, J., S. Gupta and S. Landreth-Grau: 2007, 'A Framework for Understanding Corporate Social Responsibility Programs as a Continuum: An Exploratory Study', Journal of Business Ethics 70(2), 125-140. doi:10.1007/s10551-006-9100-y.

Prencipe, A.: 2004, 'Proprietary Costs and Determinants of Voluntary Segment Disclosure: Evidence from Italian Listed Companies', European Accounting Review 13(2), 319-340. doi:10.1080/0963818042000204742.

Purushothaman, M., G. Tower, R. Hancock and R. Taplin: 2000, 'Determinants of Corporate Social Reporting Practices of Listed Singapore Companies', Pacific Accounting Review 12(2), 101-133.

Richardson, A. J. and M. Welker: 2001, 'Social Disclosure, Financial Disclosure and the Cost of Capital', Accounting, Organizations and Society 26(7/8), 597-616. doi:10.1016/S0361-3682(01)00025-3.

Robb, S. W. G., L. E. Single and M. T. Zarzeski: 2001, 'Nonfinancial Disclosures Across Anglo-American Countries', Journal of International Accounting 10(1), 71-83.
Roberts, R. W.: 1992, 'Determinants of Corporate Social Responsibility Disclosure: An Application of Stakeholder Theory', Accounting, Organizations and Society 17(6), 595-612. doi:10.1016/0361-3682(92)90015-K.

Scott, W. R.: 1987, 'The Adolescence of Institutional Theory', Administrative Science Quarterly 32(4), 493-511. doi:10.2307/2392880.

Simon, F. L.: 1992, 'Marketing Green Products in the Triad', Columbia Journal of World Business 27(3,4), 268285.

Singhvi, S. and H. Desai: 1971, 'An Empirical Analysis of the Quality of Corporate Financial Disclosure', Accounting Review 46(1), 129-138.

Ullmann, A. A.: 1985, 'Data in Search of a Theory: A Critical Examination of the Relationships Among Social Performance, Social Disclosure, and Economic Performance of U.S. Firms', Academy of Management Review 10(3), 540-557. doi:10.2307/258135.

Watts, R. L. and J. L. Zimmerman: 1986, Positive Accounting Theory (Prentice-Hall, Englewood Cliffs, $\mathrm{NJ})$.

Woodward, D. G., P. Edwards and F. Birkin: 1996, 'Organizational Legitimacy and Stakeholder Information Provision', British Journal of Management 7, 329-347. doi:10.1111/j.1467-8551.1996.tb00123.x.

Woodward, D., P. Edwards and F. Birkin: 2001, 'Some Evidence on Executives' Views of Corporate Social Responsibility', The British Accounting Review 33(3), 357-397. doi:10.1006/bare.2001.0165. 